\title{
DEVELOPMENTAL CELL DEATH IN WHEAT FLAG LEAF TIPS IN TWO WHEAT CULTIVARS
}

\author{
Kipkios TUBEI ${ }^{1}$, Lucas CHURCH ${ }^{1}, \underline{\text { Tim XING }}^{1 *}$ \\ ${ }^{1}$ Department of Biology and Institute of Biochemistry, Carleton University, Ottawa ON - Canada \\ ${ }^{*}$ Corresponding author. E-mail: tim.xing@ carleton.ca
}

\begin{abstract}
Wheat stripe rust pandemics have been recorded across all cereal growing regions. Lr34 provides an adult plant resistance and flag leaves of many wheat cultivars containing Lr34 develop a necrotic flag leaf tip. We studied cell death process in progressive necrotic and non-necrotic tissues of flag leaves in wheat cultivars Frontana (resistant to stripe rust) and Fielder (highly susceptible to stripe rust). Cleavage of the poly(ADP-ribose) polymerase (PARP) was detected in necrotic tissues of Frontana flag leaves but not in the non-necrotic tissues or in the corresponding leaf sections in Fielder flag leaves. DNA repairing genes were also studied but their expression was similar in the two different leaf sections for both cultivars. Our work may indicate that protein cleavage is involved in the cell death of flag leaf tips in Frontana.
\end{abstract}

Keywords: cell death, DNA repair, Lr34, necrosis, stripe rust, wheat.

\section{Introduction}

Cereals are a major source for protein and energy for a growing global population. To secure a successful yield, these plants must continuously defend themselves against attack from pathogens. Stripe rust is not the most prevalent diseases to affects cereal crops, and is only detected sporadically, but the damage caused can result in significant yield loss ranging from $1 \%$ to $10 \%$. [WELLINGS, 2011]. Stripe rust is caused by the pathogen Puccinia striiformis, specifically $P$. striiformis f. sp. tritici (Pst) strain in wheat.

The resistant traits in wheat either confer race specific ( $R$ gene) or non-race specific resistance. The former resistant types are dependent on the presence of effectors for infection recognition and activation of disease resistance pathways, which is often referred to Flor's gene-for-gene model [KAMOUN, 2001; XING, 2007]. Pathogens can overcome resistance by $R$ genes, as is often the case with new Pst races. The emergency of the Ug99 race of stem rust, Puccinia graminis f. sp. tritici, which is virulent to all varieties of wheat that were once resistant to stem rust $\mathrm{Sr} 24$ illustrates the ability of this pathogen to overcoming $R$ gene traits [AYLIFFE \& al. 2008]. One of the $R$ gene products in race-specific resistance is typically characterized by the presence of NBS-LRR motif, which mediates the regulation of several downstream plant defense responses including gene expression, protein modification and apoptosis [SPIELMEYER \& al. 2003]. $\operatorname{Yr} 10$ is one of the most populous $R$ gene trait employed in the wheat varieties grown in Canada.

Adult-plant resistance (APR) is a more durable form of pathogen resistance. The expression ranges from the wheat tillering stage and continues past the booting stage, which parallels the periods when wheat is susceptible to Pst infection. APR is also positively correlated to increased resistance during plant maturity [ZHANG \& al. 2012]. $Y r 18$, the most predominant APR gene conferring partial Pst incompatibility, was thought to be located in the same qualitative loci trait (QLT) site on the short arm of chromosome 7D for leaf rust 


\section{DEVELOPMENTAL CELL DEATH IN WHEAT FLAG LEAF TIPS IN TWO WHEAT CULTIVARS}

resistance gene, Lr34 [MCINTOSH, 1992; MCCALLUM \& al. 2012]. The QLT was also identified as a putative loci of powdery mildew, Blumeria graminis, resistant gene, Pm38 [SPEILMEYER \& al. 2005; LAGUDAH \& al. 2009]. Gene-specific marker based mapping and mutation work by KRATTINGER \& al. (2009) confirmed that it is a single gene, Lr34/Yr18/Pm38, confers partial resistance to leaf rust, stripe (yellow) rust and powdery mildew [LAGUDAH \& al. 2009]. The presence of an ATP-binding cassette (ABC) transporter motif within the coding region of $\mathrm{Lr34/Yr18/Pm38}$ [KRATTIGER \& al. 2009] was also confirmed and Lr34 functions as a transporter of the ABCG subfamily [KRATTIGER \& al. 2011].

Lr34 is predominantly expressed in adult foliar tissues, particularly of the flag leaf, and the highest transcript levels were found in the leaf tip, corresponding to the tissues that exhibit the phenotypic difference between the resistant and susceptible wheat lines [KRATTIGER \& al. 2009]. Wheat cultivars with functional Lr34 alleles can be distinguished phenotypically by the development of leaf tip necrosis in adult flag leaves [KRATTIGER \& al. 2009; KANG \& al. 2011]. Despite its resistance-conferring properties, Lr34 is not responsive to pathogen inoculation, suggesting that it has constitutive rather than induced functions [KANG \& al. 2011]. In spite of the significant contribution of flag leaves to the yield [DING \& al. 2018; GAJU \& al. 2011; KICHEY \& al. 2007] and as a phenotypic indicator of stripe rust resistance in different cultivars of wheat, the underlying difference in flag leaf tips of stripe rust resistant and susceptible cultivars is still unclear. In this work, we examined cell death process and the activity of DNA repairing genes in necrotic and nonnecrotic sections of flag leaf tips in a stripe rust resistant and a stripe rust susceptible cultivar.

\section{Material and methods}

\section{Plant growth}

Wheat seeds were sterilized in a solution of $70 \%$ ethanol for 2 min, then transferred to a bleach solution of $25 \mathrm{~mL}$ of bleach, $25 \mathrm{~mL}$ of distilled water and $10 \mu \mathrm{L}$ of Triton extract. The seeds were then rinsed 10 times in distilled water. After drying 5-6 seeds were potted in autoclaved Pro-mix BX soil fertilized with 7-9 granular of slow release NPK fertilizer (14:14:14). The seeds were then placed in a growth chamber (Enconnair Technologies Inc., Winnipeg, MB, Canada) set for $16 \mathrm{hr}$ at $22{ }^{\circ} \mathrm{C}$ in the light and $8 \mathrm{hr}$ at $18{ }^{\circ} \mathrm{C}$ in the dark. Plants were watered every second day. For protein and RNA extraction, leaf materials were collected and placed in Falcon tubes and snap frozen in liquid nitrogen. The materials were then stored at $-80{ }^{\circ} \mathrm{C}$.

\section{Trypan blue staining}

Cells of wheat leaves undergoing cell death were photographed using an Axioplan 2 microscope (Carl Zeiss, Germany). Methods described by TANG \& al. (1999) and STONE $\&$ al. (2000) were used with slight modifications. Leaf tissues were immersed in $10 \mathrm{~mL}$ of ethanol-lactophenol (2 volumes of ethanol and 1 volume of phenol-glycerol-lactic acid-water $(1: 1: 1: 1))$ that contained $0.05 \%$ trypan blue. The leaves were placed in $15 \mathrm{~mL}$ Falcon tubes and covered with ethanol-lactophenol-trypan blue. The samples were incubated at $95{ }^{\circ} \mathrm{C}$ for $4 \mathrm{~min}$ and then kept at room temperature for $20 \mathrm{~min}$. The staining solution was removed and $1.5 \mathrm{~mL}$ chloral hydrate destaining solution $(2.5 \mathrm{~g} / \mathrm{mL}$ of nano pure water $)$ was added to each tube. The leaves were cleared for 2 days by replacing the destaining solution twice. After 
Kipkios TUBEI \& al.

destaining, leaves were suspended in 50\% glycerol and examined under microscope with white light.

\section{Protein extraction and determination of protein concentration}

Wheat protein was extracted from leaves $(100 \mathrm{mg})$ either in extraction buffer (20 mM Tris- $\mathrm{HCl}$, pH 7.0, $150 \mathrm{mM} \mathrm{NaCl}, 1 \mathrm{mM}$ EDTA, 1 mM EGTA, $10 \mathrm{mM} \mathrm{NaF}, 1 \mathrm{mM}$ $\mathrm{NaVO}_{3}, 10 \mathrm{mM} \beta$-glycerophosphate, $1 \mathrm{mM}$ phenylmethanesulfonyl fluoride, $5 \mu \mathrm{g} / \mathrm{mL}$ aprotinin, $5 \mu \mathrm{g} / \mathrm{mL}$ leupeptin, $0.5 \%$ Nonidet P-40, and $1 \%$ Triton X-100), or using TRIzol Reagent kit (Invitrogen, Carlsbad, CA, USA) according to manufacturer's protocol. Protein concentration in tissue extracts were determined using Coomassie blue dye binding method with the Bradford reagent and bovine serum albumin (BSA) as the standard.

\section{SDS-PAGE and immunoblotting}

Detailed protocol was described previously [GAO \& al. 2011]. After SDS-PAGE and protein transfer onto nitrocellulose membranes. For antibody detection, the primary antibody used was cleaved PARP 1:1000 v:v (Cell Signaling Technology, Danvers, MA, USA). After overnight incubation with the primary antibody, blots were washed with TBST (20 mM Tris, $\mathrm{pH} \mathrm{7.5,} 150 \mathrm{mM} \mathrm{NaCl}, 0.05 \%$ Tween-20) (5 min x 3) and then incubated at room temperature for $1 \mathrm{~h}$ with 1:2000 v:v dilution of the secondary antibody (anti-rabbit IgG, horse radish peroxidase-linked) (Cell Signaling Technology, Danvers, MA, USA). The target protein on the PVDF membrane was detected using an enhanced chemiluminescence (ECL) system containing $1 \mathrm{x}$ LumiGLO Reagent and 1x peroxide (Cell Signaling Technology, Danvers, MA, USA). The membrane was scanned using FluorChem Q imaging system (Alpha Innotech Cooperation, Santa Clara, CA, USA).

\section{RNA extraction and RT-PCR}

Total RNA was extracted from wheat leaf tissues $(100 \mathrm{mg})$ using TRIzol Reagent kit (Invitrogen, Carlsbad, CA, USA) according to manufacturer's protocol. After TRIzol extraction, DNase I kit (amplification grade, Invitrogen, Carlsbad, CA, USA) was used to eliminate genomic DNA contamination in the sample, and the cloned AMV First-Strand cDNA Synthesis Kit (Invitrogen, Carlsbad, CA, USA) was used for cDNA synthesis according to the manufacturer's protocol.

The primers for RAG50 were 5'-CAGGGACACATTGACTGGTG-3' (forward) and 5'-TTTCCTCGGCAAAATGTACC-3' (reverse). The following conditions were used for RTPCR: $94{ }^{\circ} \mathrm{C}$ for $1 \mathrm{~min} ; 94^{\circ} \mathrm{C}$ for $1 \mathrm{~min}, 67^{\circ} \mathrm{C}$ for $1 \mathrm{~min}, 72^{\circ} \mathrm{C}$ for 30 seconds for 28 cycles, and then $72{ }^{\circ} \mathrm{C}$ for $10 \mathrm{~min}$. The primers for RAD51 were 5'CAGAAGGCACATTCAGACCA-3' (forward) and 5'-GCAAACCTTGTCTCCACCAT-3' (reverse). The following conditions were used for RT-PCR: $94{ }^{\circ} \mathrm{C}$ for $1 \mathrm{~min} ; 94{ }^{\circ} \mathrm{C}$ for 1 min, $71{ }^{\circ} \mathrm{C}$ for $1 \mathrm{~min}, 72{ }^{\circ} \mathrm{C}$ for 30 second for 28 cycles, and then $72{ }^{\circ} \mathrm{C}$ for $10 \mathrm{~min}$. GAPDH (glyceraldehyde-3-phosphate dehydrogenase, GenBank accession number EU022331.1) gene was used as an internal standard [LLOYD \& al. 2007]. For RT-PCR, the primers were 5'-GTGAGGCTGGTGCTGATTACG-3' (forward) and 5'TGGTGCAGCTAGCATTTGAGAC-3' (reverse). The following conditions were used for RT-PCR: $94{ }^{\circ} \mathrm{C}$ for $1 \mathrm{~min} ; 94^{\circ} \mathrm{C}$ for $1 \mathrm{~min}, 60^{\circ} \mathrm{C}$ for $1 \mathrm{~min}$, and $72{ }^{\circ} \mathrm{C}$ for 30 seconds for 28 cycles, and then $10 \mathrm{~min}$ at $72{ }^{\circ} \mathrm{C}$. 


\section{Results}

\section{Cell death in flag leaf tips}

Wheat cultivars with functional $\operatorname{Lr} 34$ alleles are phenotypically different from cultivars carrying no Lr34, and have a typical leaf tip necrosis in adult flag leaves [KRATTIGER \& al. 2009; KANG \& al. 2011]. Frontana (stripe rust resistant) and Fielder (stripe rust susceptible) [RANDHAWA \& al. 2012] were selected for this work. Both cultivars were grown under identical conditions, and no significant differences were observed in development. The flag leaf tips of both cultivars were harvested at the beginning of the grain-filling stage. Cell death was examined on leaves detached from Frontana and Fielder. Trypan blue is commonly used to selectively stain dead tissues or cells blue, and under white light the dead cells appeared to be much darker compared to living cells. These blue dead cells scattered on leaves as clusters without defined margins and the cell death did not seem to occur in the whole leaf. The heavily blue staining areas represent cell death and Frontana showed much more significant cell death than Fielder (Figure 1).
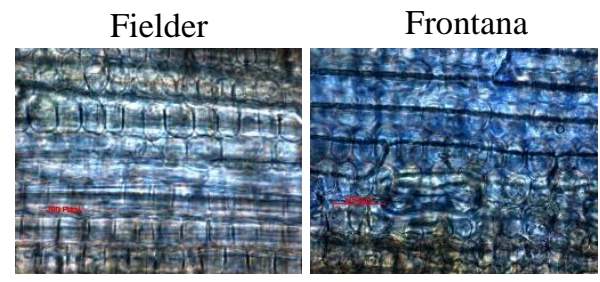

Figure 1. Microscopic images of flag leaves from Fielder and Frontana. Leaf tips of Fielder (left) and Frontana (right) $1 \mathrm{~cm}$ from the tip were stained with trypan blue.

Repeat experiment showed a similar result.

\section{Cleavage of poly(ADP-ribose) polymerase (PARP)}

Cleavage of key proteins by caspases is often taken as an indicator of cell death activity. Poly(ADP-ribose) polymerase (PARP) is among the first target proteins shown to be specifically cleaved by caspases [FAN \& XING, 2004]. PARP is involved in the regulation of repairing DNA strand breaks and in cell recovery from DNA damage, so the physiological function of PARP includes DNA repair, DNA replication and maintenance of genome integrity [DE BLOCK \& al. 2005]. To evaluate the possible involvement of caspases in cell death of flag leaf tips, we examined the integrity of PARP proteins in the leaf sections showing cell death progress (the first $\mathrm{cm}$ from the tip) and green sections (the second $\mathrm{cm}$ from the tip). Cleavage of PARP was detected in flag leaf tips of Frontana but not the corresponding tip tissue of Fielder (Figure 2). The cleavage was not detected in the green tissues below the flag leaf tips (Figure 2). 


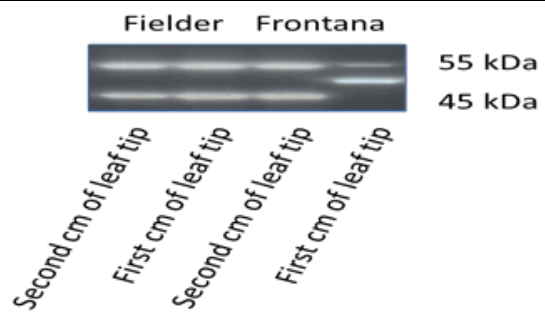

Figure 2. PARP status in flag leaf tips and in tissues below the tips detected by the antibody against cleaved PARP. Proteins were extracted from flag leaf tips of Frontana and Fielder the first $1 \mathrm{~cm}$ from the tip and the second $1 \mathrm{~cm}$ from the tip. Three experiments were carried out with similar results.

\section{Expression of Radiation Sensitive 50 (RAD 50) and RAD 51}

Plants are equipped with mechanisms to detect and repair multiple types of DNA lesions . It is possible that the cell death in flag leaf tips of Frontana and Fielder is regulated by DNA repairing capacity. DNA repairing genes including RAD50 and RAD51 have been identified in yeast, animals and plants and they are involved in various processes such as DNA damage repairing, DNA replication, meiosis, and telomere maintenance (BLEUYARD \& al. 2005; LLOYD \& al. 2007; SONG \& al. 2011]. To examine whether RAD50 and RAD51 contribute to the difference of the leaf tip cell death between Fielder and Frontana, their expression levels was examined by RT-PCR (Figure 3). There was no significant difference in the expression levels of either RAD50 or RAD51 in the two cultivars.

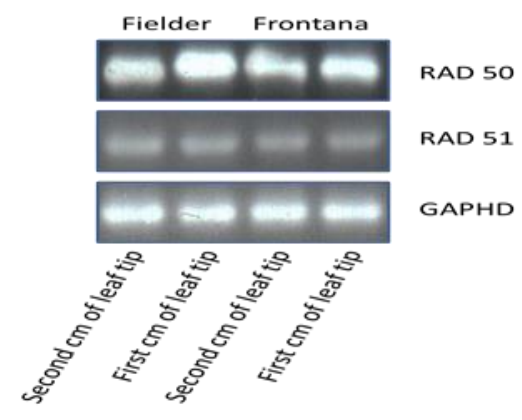

Figure 3. Expression of DNA repairing genes in flag leaf tips of Frontana and Fielder. GAPDH gene was used as an internal standard. Three experiments were carried out with similar results.

\section{Discussion}

Stripe rust can cause significant crop damage resulting in yield lose ranging from $1 \%$ to $10 \%$ [WELLINGS, 2011]. Wheat is specifically affected by $P$. striiformis $\mathrm{f}$. sp. tritici (PST) strain. Resistance gene Lr34 is predominantly expressed in the flag leaf and the expression correlates to cell death difference between the resistant and susceptible wheat cultivars [KRATTIGER \& al. 2009; KANG \& al. 2011]. This difference was confirmed in Frontana (resistant) and Fielder (susceptible) (Figure 1). 
Cell death is mediated by the activities of protein cleavage enzymes. Activities displaying caspase cleavage specificity have been shown in cell death in various plant species including wheat [XING \& al. 2005; FAN \& al. 2016]. Genomic and molecular genetic approaches have supported the existence of caspase-like proteases in plants [VARTAPETIAN $\&$ al. 2011]. When we examined the caspase-like activity in flag leaf tips, cleavage of PARP was detected in flag leaf tips of Frontana but was undetectable in the corresponding tip tissue of Fielder. No cleavage was detected in green tissues below the flag leaf tips (Figure 2). Early work indicated PARP activity in wheat embryo cells [WHITBY \& al. 1977, 1978, 1979]. However, our previous work showed no success in identifying TGYMFGKG, a PARP signature sequence, in wheat [XING \& al. 2004]. On the other hand, a non-canonical PARP domain proteins was shown to act in stress responses in wheat [LIU \& al. 2014].

As plant cells are subject to high levels of DNA damage resulting from dependence on sunlight for energy and the concomitant exposure to environmental stresses, mechanisms developed to sense the damage and to activate the DNA repair machinery to preserve the genome content [CIMPRICH \& CORTEZ, 2008; DEVISETTY \& al. 2010]. The expression levels of two DNA repair genes RAD50 and RAD51 in flag leaf tips of Frontana and Fielder were determined by semi-quantitative RT-PCR and no difference was found (Figure 3). However, since many other DNA repairing genes could be involved, it is reasonable to assume that its expression may not necessarily be altered as indicated in our previous study [ALBARAKY, 2008].

Our current work has suggested the involvement of a PARP-like protein in the phenotypic difference in cell death in wheat flag leaf tips between Frontana and Fielder. Questions still remain such as whether localized ability to regulate cell death may prime the stripe rust resistant cultivars against potential attack of stripe rust and how the cell death in flag leaf tips is integrated in Lr34-mediated stripe rust resistance.

\section{Notes on contributors}

Kipkios TUBEI is a MSc. student supported by a research grant from Bayer Crop Science Inc.

Lucas CHURCH is an undergraduate student.

Tim XING is an associate professor and a plant molecular biologist with a special interest in cell signaling and plant-microbe interactions. He teaches plant physiology, molecular plant development, and cell signaling.

\section{Acknowledgements}

This work was supported by a research grant to T.X. from Bayer Crop Science Inc. and Carleton University, Canada.

\section{References}

ALBARAKY A. O. 2008. Molecular and cellular analysis of disease resistance mechanisms in wheat. MSc Thesis, Carleton University, Department of Biology, Ottawa, Canada.

AYLIFFE M., SINGH R. \& LAGUDAH E. 2008. Durable resistance to wheat stem rust needed. Current Opinion in Plant Biology. 11: 187-192. https://doi.org/10.1016/j.pbi.2008.02.001

BLEUYARD J. Y., GALLEGO J. E., SAVIGNY F. \& WHITE C. I. 2005. Differing requirements for the Arabidopsis Rad51 paralogs in meiosis and DNA repair. The Plant Journal. 41: 533-545. https://doi.org/10.1111/j.1365-313X.2004.02318.x

CIMPRICH K. A. \& CORTEZ D. 2008. ATR: An essential regulator of genome integrity. Nature Reviews Molecular Cell Biology. 9: 616-627. https://doi.org/10.1038/nrm2450 
Kipkios TUBEI \& al.

DE BLOCK M., VERDUYN C., DE BROUWER D. \& CORNELISSEN M. 2005. Poly(ADP-ribose) polymerase in plants affects energy homeostasis, cell death and stress tolerance. The Plant Journal. 41: 95-106. https://doi.org/10.1111/j.1365-313X.2004.02277.x

DEVISETTY U. K., MAYES K. \& MAYES S. 2010. The RAD51 and DMC1 homologous genes of bread wheat: cloning, molecular characterization and expression analysis. BMC Research Notes. 3: 245. https://doi.org/ 10.1186/1756-0500-3-245

DING H., LIU D., LIU X., LI Y., KANG J., LV J. \& WANG G. 2018. Photosynthetic and stomatal traits of spike and flag leaf of winter wheat (Triticum aestivum L.) under water deficit. Photosynthetica. 56: 687. https://doi.org/ 10.1007/s11099-017-0718-z

FAN T. \& XING T. 2004. Heat shock induces programmed cell death in wheat leaves. Biologia Plantarum. 48: 389394. https://doi.org/10.1023/b:biop.0000041091.03068.ee

FAN T., BYKOVA N., RAMPITSCH C. \& XING T. 2016. Identification and characterization of a serine protease from wheat leaves. European Journal of Plant Pathology. https://doi.org/10.1007/s10658-016-0914-X

GAJU O., ALLARD V., MARTRE P., SNAPE J. W., HEUMEZ E., LEGOUIS J., MOREAUB D., BOGARD M., GRIFFITHS S., ORFORD S., HUBBART S. \& FOULKES M. J. 2011. Identification of traits to improve the nitrogen-use efficiency of wheat genotypes. Field Crops Research. 123: 139-152. https://doi.org/ 10.1016/j.fcr.2011.05.010

GAO Y., LIU X., STEBBING J., HE D., LAROCHE A., GAUDET D. \& XING T. 2011. TaFLRS, a novel mitogenactivated protein kinase in wheat defense responses. European Journal of Plant Pathology. 131: 643651. https://doi.org/10.1007/s10658-011-9837-8

KAMOUN S. 2001. Nonhost resistance to Phytophthora: novel prospects for a classical problem. Current Opinion in Plant Biology. 4: 295-300. https://doi.org/10.1016/S1369-5266(00)00176-X

KANG J., PARK J., CHOI H., BURLA B., KRETZSCHMAR T., LEE Y. \& MARTINOIA E. 2011. Plant ABC transporters. IN: Arabidopsis Book 9:e0153. https://doi.org/10.1199/tab.0153

KICHEY T., HIREL B., HEUMEZ E., DUBOIS F. \& LE GOUIS J. 2007. In winter wheat (Triticum aestivum L.), post-anthesis nitrogen uptake and remobilisation to the grain correlates with agronomic traits and nitrogen physiological markers. Field Crops Research. 102: 22-32. https://doi.org/10.1016/j.fcr.2007.01.002

KRATTINGER S. G., LAGUDAH E. S., SPIELMEYER W., SINGH RP., HUERTA-ESPINO J., MCFADDEN H., BOSSOLINI E., SELTER L. L. \& KELLER B. 2009. A putative ABC transporter confers durable resistance to multiple fungal pathogens in wheat. Science. 323: 1360-1363. https://doi.org/10.1126/science.1166453

KRATTINGER S. G., LAGUDAH E. S., WICKER T., RISK J. M., ASHTON A. R., SELTER L. L., MATSUMOTO T. \& KELLER B. 2011. Lr34 multi-pathogen resistance ABC transporter: molecular analysis of homoeologous and orthologous genes in hexaploid wheat and other grass species. The Plant Journal. 65 : 392-403. https://doi.org/10.1111/j.1365-313X.2010.04430.x

LAGUDAH E. S., KRATTINGER S. G., HERRERA-FOESSEL S., SINGH R. P., HUERTA-ESPINO J., SPIELMEYER W., BROWN-GUEDIRA G., SELTER L. L. \& KELLER B. 2009. Gene-specific markers for the wheat gene Lr34/Yr18/Pm38 which confers resistance to multiple fungal pathogens. Theoretical and Applied Genetics. 119: 89-98. https://doi.org/10.1007/s00122-009-1097-z

LIU S., LIU S., WANG M., WEI T., MENG C., WANG M. \& XIA G. 2014. A wheat SIMILAR TO RCD-ONE gene enhances seedling growth and abiotic stress resistance by modulating redox homeostasis and maintaining genomic integrity. Plant Cell. 26: 164-180. https://doi.org/10.1105/tpc.113.118687

LLOYD A., MILLIGAN A. S., LANGRIDGE P. \& ABLE J. 2007. TaMSH7: A cereal mismatch repair gene that affects fertility in transgenic barley (Hordeum vulgare L.). BMC Plant Biology. 7: 67. https://doi.org/10.1186/1471-2229-7-67

MCCALLUM B. D., HUMPHREYS D. G., SOMERS D. J., DAKOURI A. \& CLOUTIER S. 2012. Allelic variation for the rust resistance gene Lr34/Yr18 in Canadian wheat cultivars. Euphytica. 183: 261-274. https://doi.org/ 10.1007/s10681-011-0519-6

MCINTOSH R. A. 1992. Close genetic linkage of genes conferring adult-plant resistance to leaf rust and stripe rust in wheat. Plant Pathology. 41: 523-527. https://doi.org/10.1111/j.1365-3059.1992.tb02450.x

RANDHAWA H., PUCHALSKI B. J., FRICK M., GOYAL A., DESPINS T., GRAF R. J., LAROCHE A. \& GAUDET D. A. 2012. Stripe rust resistance among western Canadian spring wheat and triticale varieties. Canadian Journal of Plant Science. 92: 713-722. https://doi.org/10.4141/cjps2011-252

SONG J., DURRANT W. E., WANG S., YAN S., TAN E. H. \& DONG X. 2011. DNA repair proteins are directly involved in regulation of gene expression during plant immune response. Cell Host \& Microbe. 9: 115124. https://doi.org/10.1016/j.chom.2011.01.011 


\section{DEVELOPMENTAL CELL DEATH IN WHEAT FLAG LEAF TIPS IN TWO WHEAT CULTIVARS}

SPIELMEYER W. \& LAGUDAH E. S. 2003. Homoeologous set of NBS-LRR genes located at leaf and stripe rust resistance loci on short arms of chromosome 1 of wheat. Functional and Integrative Genomics. 3: 8690. https://doi.org/10.1007/s10142-002-0074-2

SPIELMEYER W., MCINTOSH R. A., KOLMER J. \& LAGUDAH E. S. 2005. Powdery mildew resistance and Lr34/Yr18 genes for durable resistance to leaf and stripe rust cosegregate at a locus on the short arm of chromosome 7D of wheat. Theoretical and Applied Genetics. 111: 731-735. https://doi.org/10.1007/s00122-005-2058-9

STONE J. M., HEARD J. E., ASAI T. \& AUSUBELF. M. 2000. Simulation of fungal-mediated cell death by fumonisin B1 and selection of fumonisin B1-resistant (fbr) Arabidopsis mutants. Plant Cell. 12: 1811-1822. https://doi.org/ 10.1105/tpc.12.10.1811

TANG X., XIE M., KIM Y., ZHOU J., KLESSIG D. \& MARIN G. 1999. Overexpression of Pto activates defence response and confers broad resistance. Plant Cell. 11: 15-29. https://doi.org/10.1105/tpc.11.1.15

VARTAPETIAN A. B., TUZHIKOV A. I., CHICHKOVA N. V., TALIANSKY M. \& WOLPERT T. J. 2011. A plant alternative to animal caspases: subtilisin-like proteases. Cell Death \& Differentiation. 18: 1289-1297. https://doi.org/10.1038/cdd.2011.49

WELLINGS C. 2011. Global Status of Stripe rust: A review of historical and current threats. Euphytica. 179: $129-141$. https://doi.org/10.1007/s10681-011-0360-y

WHITBY A. J. \& WHISH W. J. 1977. Poly(adenosine diphosphate ribose) in wheat. Biochemical Society Transactions. 5: 948-949. https://doi.org/10.1042/bst0050948

WHITBY A. J. \& WHISH W. J. 1978. Poly(adenosine diphosphate ribose) glycohydrolase in germinating wheat embryos. Biochemical Society Transactions. 6: 619-620. https://doi.org/10.1042/bst0060619

WHITBY A. J., STONE P. R. \& WHISH W. J. 1979. Effect of polyamines and $\mathrm{Mg}^{++}$on poly(ADP-ribose) synthesis and ADP-ribosylation of histones in wheat. Biochemical and Biophysical Research Communications. 90: 1295-1304. https://doi.org/10.1016/0006-291x(79)91177-X

XING T. 2007. Signal transduction pathways and disease resistant genes and their applications to fungal disease control. In: PUNJA Z. K., BE BOER S. H. \& SANFAÇON H. (ed.) Biotechnology and Plant Disease Management, CAB International, UK: 1-15.

XING T., FAN T., HAN S. Y., DJURIC-CIGANOVIC S., JORDAN M. \& WANG X. J. 2005. Programmed cell death in plant disease resistance: pathways and components. Recent Research Development in Bioenergetics. 3: 33-44.

ZHANG H., WANG C., CHENG Y., CHEN X., HAN Q., HUANG L., WEI G. \& KANG Z. 2012. Histological and cytological characterization of adult plant resistance to wheat stripe rust. Plant Cell Reports. 31: 21212137. https://doi.org/10.1007/s00299-012-1322-0

How to cite this article:

TUBEI K., CHURCH L. \& XING T. 2019. Developmental cell death in wheat flag leaf tips in two wheat cultivars. J. Plant Develop. 26: 109-116. https://doi.org/10.33628/jpd.2019.26.1.109 